\title{
Australské standardy pro práci s rodinou v paliativní péči: zkušenosti z praxe zavádění organizační změny ${ }^{1}$ Naděžda Adámková, Michal Růžička
}

\begin{abstract}
Abstrakt
Článek zprostředkovává praktickou zkušenost s organizační změnou multidisciplinárního týmu domácí hospicové péče v podobě zavádění australských standardů pro př́ijem pacienta do domácí hospicové péče. Cílem první fáze výzkumné části bylo zmapovat stávající praxi příjmu pacienta do domácí hospicové péče, identifikovat potřeby týmu a připravit pưdu pro implementaci organizační změny. Na základě získaných dat byly v týmu konsensuálně vybrány čtyři standardy pro př́ijem pacienta, které byly $v$ další fázi implementovány po dobu tří měsíců do praxe. Poslední fáze spočívala ve společné reflexi implementačního procesu. Předkládaný článek podrobně popisuje všechny dílčí fáze z pohledu praktické zkušenosti, na závěr pak předkládá doporučení, ze kterých mohou čerpat i jiné organizace při optimalizaci postupu práce v týmech domácí hospicové péče.
\end{abstract}

Klíčová slova: paliativní péče, domácí hospic, domácí hospicová péče, příjem pacienta, multidisciplinární tým

\section{Úvod}

Paliativní péče je rozvíjejícím se oborem, který se postupně prosazuje jako součást péče o klienty zdravotnických a sociálních služeb jak v zahraničí, tak v České republice ${ }^{2}-$ a postupně se etabluje do diskurzů nejen lékařské vědy a etiky, ale např. i sociální práce. ${ }^{3}$ Vedle hospicové péče se paliativní péče stále více prosazuje jako př́stup orientovaný na člověka nejen v prostředí ústavní péče ${ }^{4}$, ale také jako typ zdravotnické/sociální péče poskytované v domácím prostředí pacienta/klienta. Přestože paliativní péče postupně získává pozornost nejen odborné

1 Tento text je upravenou verzí diplomové práce Naděždy Adámkové, kterou v roce 2018 úspěšně obhájila na Katedře řízení a supervize FHS UK: @ Univerzita Karlova, Domácí hospicová péče - možnost využití australských standardů při př́imu pacienta (on-line), dostupné na: https://dspace.cuni.cz/handle/20.500.11956/99678, citováno dne 30. 8. 2020. Realizátorkou výzkumných prací a autorkou tabulek je též Naděžda Adámková.

2 Elizabeth DAVIES - Irene HIGGINSON, Palliative care: The Solid Facts, New York: World Health Organization, 2004; Ondřej SLÁMA, Paliativní a hospicová péče v České republice a v Evropě, Klinická onkologie 4/2009, s. 183-185; Radka BUŽGOVÁ, Paliativní péče ve zdravotnických zařizeních: potřeby, hodnocení, kvalita života, Praha: GRADA, 2015.

3 Henk TEN HAVE - David CLARK (eds.), The Ethics of Palliative Care: European Perspectives, Philadelphia: Open University Press, 2002 Terry ALTILIO - Shirley OTIS-GREEN, Oxford Textbook of Palliative Social Work, Oxford: Oxford University Press, 2001.

4 Karolína PECHOVÁ - Martin LOUČKA, Plánování péče v závěru života v pobytových sociálních službách pro seniory, Sociální práce / Sociálna práca 6/2019, s. 112-126. 
veřejnosti, ale i veřejnosti laické, stále není tento přístup $\mathrm{k}$ péči o člověka $\mathrm{v}$ poslední fázi jeho života rozšířený natolik, aby jej bylo možné považovat za běžně dostupnou a garantovanou zdravotní a sociální službu. ${ }^{5}$

Přestože je v současné době paliativní a hospicová péče stále častěji medializovaná, řada lidí netuší, co to „hospic“ je. Otázka smrti nadále zůstává tabu, často vyvolává pocity úzkosti a strachu, lidé nejsou zvyklí o podobných tématech hovořit. U části populace vládne názor, že nemocný patři do nemocnice. Pokud je však léčba ukončena a pacient poslán lékaři domů, nastane často panika. Mnoho pacientů nemá dostatek informací o své další cestě s nevyléčitelnou nemocí. Obvykle spadají do péče praktického lékaře, který by měl být schopen základní paliativní léčbu nastavit. V prrípadě, že péče není zvladatelná v domácím prostředí, je pacient často odesílán zpět do nemocnice. Dle výzkumu z roku 2013 by si 78 \% lidí přálo zemřít v domácím prostředí. Realita je bohužel taková, že skoro 60 \% lidí zemře v nemocnicích, 20 \% v domovech pro seniory a zhruba $20 \%$ doma nebo náhle v terénu. ${ }^{6}$

První autorka předkládaného textu se v oblasti paliativní péče angažuje profesně jako zdravotní sestra $\mathrm{v}$ domácím hospicu a jako koordinátorka domácí hospicové péče. Ze své pozice vnímala, že v organizaci, ve které pracuje, existuje v některých oblastech prostor pro optimálnější uspořádání a organizaci postupů práce týmu. Proto se pokusila nejen o analýzu procesu př́ijmu nového pacienta do domácí hospicové péče, ale také o implementaci změny, která by vedla k vyšší kvalitě péče o klienty.

Předkládaný článek popisuje praktickou zkušenost se zaváděním organizační změny do multidisciplinárního týmu domácí hospicové péče. Tým v organizaci, ve které probíhal výzkum a experimentální implementace změny, původně vznikl jako malá skupina dobrovolníků - odborníků, zdravotníků, kteří chtěli pacientům trpícím na samém konci života pomáhat v jejich přirozeném prostředí, a tím jim splnit jedno z jejich posledních přání - zemřít doma $\mathrm{v}$ náruči lásky vlastní rodiny. Tým byl původně malý, ale na základě zvyšující se poptávky žadatelů o domácí hospicovou péči se rozrostl do současného cca třicetičlenného uskupení, v němž je nezbytná efektivní koordinace práce. $\mathrm{V}$ opačném př́ípadě by mohl mít vzniklý chaos negativní dopad na kvalitu poskytované péče. $Z$ tohoto důvodu samotní členové týmu konsenzuálně zvolili několik standardů australské paliativní péče ke zkušební implementaci. Společným cílem bylo vyzkoušení, resp. zavedení změny, která by byla k užitku jak pacientům, tak organizaci samotné, přičemž primárním záměrem bylo zefektivnění koordinace práce týmu a tím i zvýšení kvality poskytovaných služeb.

Cílem první fáze výzkumné části bylo zmapování a analýza současné praxe př́ímu pacienta do domácí hospicové péče ve zkoumané organizaci, identifikace potřeb týmu a příprava půdy pro implementaci organizační změny. Na základě získaných dat byly v týmu konsensuálně vybrány 4 standardy pro prŕijem pacienta do domácí hospicové péče, které byly v další fázi implementovány do praxe po dobu tří měsíců. Poslední fáze spočívala ve společné reflexi implementačního procesu a kolektivním zhodnocení, zda byla daná zkušenost pro tým něčím prospěšná. Předkládaný článek podrobně popisuje všechny dílčí fáze tohoto procesu z pohledu praktické zkušenosti, na závěr pak předkládá doporučení, ze kterých mohou čerpat i jiné organizace př̀i optimalizaci postupu práce v týmech domácí hospicové péče.

5 Ondřej SLÁMA - Ladislav KABELKA - Martin LOUČKA, Paliativní péče v ČR v roce 2016, Časopis lékařo českých 8/2016, s. 445-450.

6 C Cesta domů, o. p. s., Smrt a péče o umírající (on-line), dostupné na: http://www.cestadomu.cz/res/data/053/006112.pdf, citováno dne 9. 8. 2017. 


\section{Principy a standardy paliativní péče}

Nejčastěji užívaná definice byla vyjádřena Světovou zdravotnickou organizací (WHO), která ř́ká, že „Paliativní péče je př́stup, který usiluje o zlepšení kvality života pacientů a rodin, kteří čelí problémům spojeným s život ohrožujícím onemocněním, a to prostřednictvím prevence a zmírňování utrpení včasnou identifikací a dokonalým zhodnocením a léčbou a mírněním bolesti a dalších problémů, fyzických, psychosociálních i duchovních“7. Další výstižnou definicí je definice Evropské asociace pro paliativní péči (EAPC): „Paliativní péče představuje aktivní celkovou péči o pacienta, jehož onemocnění neodpovídá na kurativní léčbu. Zásadně důležité je mírnění bolesti a dalších příznaků, sociálních, psychologických a duchovních problémů. Paliativní péče je ve svém př́stupu interdisciplinární a do své působnosti zahrnuje pacienta, rodinu a komunitu. Paliativní péče ctí a chrání život. Umírání a smrt považuje za normální proces, smrt však ani neurychluje, ani neoddaluje. Usiluje o zachování maximální možné kvality života až do smrti“" ${ }^{\text {. }}$. Všechny definice mají společný základ, a to zmírnění utrpení, důstojnost, zachování kvality života po maximální možnou dobu a všestrannou podporu nemocného a jeho blízkých.

Na obecné rovině představují standardy soubor doporučujících předpisů, které mají obecný charakter. Určují minimální úroveň kvality péče, která by měla být vždy dodržována zařízeními poskytujícími specializovanou paliativní péči. Pakliže se standardy stanou součástí smlouvy mezi zařízením a pacientem, stávají se závaznými.

Standardy představují základní východiska hospicové paliativní péče, jako jsou principy, cílová skupina, indikace $\mathrm{k}$ hospicové péči a základní organizační formy. Dále obsahují podrobný plán péče o tělesný, duchovní, psychický a sociální stav, etické, právní a kulturní aspekty péče. „Nedílnou součástí jsou personální standardy pro lůžkový a mobilní hospic a materiálně technické vybavení. “9

Týmy i jednotlivci poskytující paliativní péči si musejí uvědomovat cíle hospicové péče. Při práci by měli využívat veškeré své schopnosti, osobní vlastnosti a umění empatie při komunikaci s každým jednotlivým pacientem. Dále by měli posoudit a zajistit nemocnému důstojné, profesionální doprovázení zbytkem jeho dnů. Podstatou péče je kvalita a uspokojení potřeb pacienta. Pečující personál se snaží šetrně zapojit do doprovázení rodinu a blízké, kteří jsou součástí prostředí nemocného. Definice kvality života je těžko formulovatelná, zejména proto, že se v průběhu života mění. Profesionální personál je schopen operativně reagovat na individuální potřeby konkrétního pacienta. „Základním principem pro splnění vymezených cílů je častá komunikace nejen s nemocným, ale hlavně s doprovázejícími členy rodiny. ${ }^{\text {"10 }}$ Pracovníci v tomto oboru musejí respektovat životní hodnoty pacienta i v prrípadě, že se liší od hodnot ostatních lidí i jich samotných. Všeobecně, $\mathrm{v}$ základní linii se používá dělení paliativní péče na paliativní péči obecnou a specializovanou. Každá z nich má své specifické určení v poskytování konkrétních služeb. Jedná se zejména o ošetřovatelskou péči a naplňování bio, psycho, sociálních služeb a poskytování psychické opory nemocným a jejich rodinám.

Obecná paliativní péče by měla být dostupná ve všech zařízeních poskytujících zdravotnické služby, a to $\mathrm{v}$ rozsahu, kterého je nespecializované zdravotnické zařízení schopno, přičemž takovou

Lukas RADBRUCH - Sheila PAYNE a kol., Standardy a normy hospicové a paliativní péče v Evropě, Praha: Cesta domů, 2010 , s.16. Tamtéž, s. 16.

9 @ APHPP, Hospice v $\check{C} R$ (on-line), dostupné na: http://www.asociacehospicu.cz/wp-content/uploads/2017/01/STANDARDY\%202016. pdf, citováno dne 9. 8. 2017.

10 Radek PTÁČEK - Petr BARTU゚NĚK a kol., Eutanazie - pro a proti, Praha: Grada, s. 64. 
„péči by měl umět poskytnout každý zdravotník bez ohledu na svoji odbornost. " ${ }^{11}$ Každý zdravotník by měl být schopen detekovat a operativně přizpůsobovat všechny procesy důležité pro zkvalitnění posledních chvil pacientova života.

Odbornou interdisciplinární péči nazýváme specializovaná paliativní péče. Je nutné, aby byla poskytována týmem odborníků, který je svým zaměřením, vzděláním a praxí připraven k poskytování právě této péče. Odborný specializovaný tým obvykle bývá multidisciplinárním seskupením složeným z lékařů, psychologů, sester, ošetřovatelů, sociálních pracovníků, fyzioterapeutů, ergoterapeutů a duchovních. Často se $\mathrm{k}$ doplnění týmu využívá také sítě dobrovolníků. Koncepce specializované paliativní péče v České republice má několik forem: domácí paliativní péči - domácí/ mobilní hospic, hospic lůžkový, oddělení paliativní péče při lůžkových zdravotnických zařízeních, konziliární týmy paliativní péče, specializované ambulance paliativní péče, denní stacionáře paliativní péče atd.

Domácí hospicové týmy zajištují péči v přirozeném prostředí $\mathrm{v}$ nepřetržitém provozu. Zásadní pro pacienta a rodinu je dostupnost a komplexnost. Tyto týmy pracují s vědomím, že kdykoli mají kam zavolat, kde o pacientově stavu vědí vše podstatné, díky čemuž je mu tým schopen velmi rychle pomoci od náhle vzniklých obtíží. Proto je domácí hospic nejžádanější formou péče ze strany pacientů. Mnoho z nás by si přálo zůstat v takové chvíli doma, přičemž „Česká republika $\mathrm{v}$ tomto ohledu má ještě rezervy před okolním světem. “12 Lůžkové zařízení „hospic“ pečuje o pacienty, kteří nemohou zůstat doma. V některých zdravotnických zařízeních, jako jsou nemocnice a léčebny, nově vznikají oddělení paliativní péče. Specializovaná ambulantní péče je vhodná pro pacienty, kteři jsou ještě schopni samostatně docházet $\mathrm{z}$ domova. Zpravidla má formu ordinace a zabývá se zejména léčbou bolesti. Denní stacionáře a centra denních služeb jsou určena pro pacienty, kteř́ jsou ještě schopni tato centra navštěvovat. Personál zde nabízí aktivity, které jsou v pacientových aktuálních silách, např. relaxace, cvičení a dále psychickou podporu v kolektivu ostatních klientů. Zdravotnická zařízení ambulantního typu jsou vhodná pro nemocné, kteří bez problémů zvládnou přepravu $\mathrm{z}$ domu do takového zařízení, tudíž ještě nejsou upoutáni na lůžko. V takovém stavu mohou také navštěvovat denní stacionáře. Určují si sami, kdy přijdou a jak dlouho zvládnou pobýt. Pravidelnost jejich návštěv se odvíjí od momentálního stavu a potřeb. Další důležitou formou pomoci při této péči jsou různé poradny, které pacienty či jejich př́ibuzné nasměrují na další existující organizace, které jim v jejich nelehkém údělu pomohou. Mohou to být centra dobrovolníků, půjčovny zdravotnických pomůcek, různé tísňové linky a sdružení specializovaná pro tento obor.

\section{Př́ijem pacienta do domácího hospice}

Protože se v článku na praktické rovině věnujeme problematice přijímání pacienta do péče domácího hospice, přiblížíme si nyní v této kapitole prostředí, ve kterém se projekt realizoval. Nezbytným předpokladem přijetí do domácího hospice je přání a souhlas pacienta s péčí v jeho domácím prostředí. Rodina nebo blízcí musejí být schopni o pacienta v domácím prostř̌edí pečovat. Praktický lékař pacienta by měl být ochoten spolupracovat zejména při předepisování léků a pomůcek. Všichni zúčastnění chápou stejným způsobem klinickou situaci, uvědomují si, že pacient je nevyléčitelně nemocný. Cílem péče je udržení dobré kvality života v domácím prostředí. Všechny praktické aspekty péče jsou zvládnutelné v domácím prostředí, včetně řešení akutních či kritických situací.

11 Alena ŠAFRÁNKOVÁ - Marie NEJEDLÁ, Interní ošetřovatelství II, Praha: Grada, 2006, s. 57.

12 Marie SVATOŠOVÁ, Hospice a umění doprovázet, Kostelní Vydř́i: Karmelitánské nakladatelství, 2011, s. 31. 
Pacient se dostává do péče domácího hospice ve fázi, kdy si již doma sám neví rady a ani jeho blízcí již sami péči nezvládají. Někdy je teprve tento stav donutí podat žádost o domácí hospicovou péči. Bohužel často bývá delší čekací doba a hospic nemá kapacitu pro okamžité přijetí žadatele. Proto je vhodné podat žádost s předstihem, a to i v prŕpadě, že nemocný službu nakonec nevyužije. Tým domácího hospice přijímá pacienta nejčastěji v době nevratně progredujícího nebo terminálního stavu nemoci. Prognóza přežití těchto nemocných bývá většinou dny a týdny, výjimečně měsíce. Mezi podmínky pro přijetí pacienta do domácího hospice patří zejména to, že trpí nevyléčitelným onemocněním $\mathrm{v}$ pokročilém nebo konečném stadiu, byl seznámen se svým zdravotním stavem a přiměřeně svému stavu porozuměl. Dále je potřeba, aby chápal principy i limity domácí hospicové péče a souhlasil s péči v domácím prostředí. $O$ přijetí rozhoduje lékař na základě kategorizace zdravotního stavu pacienta.

Mezi nutné podmínky pro přijetí pacienta do domácího hospice patří plná informovanost pečujících o zdravotním stavu pacienta. Pečující osoby by měly, přiměřeně svým možnostem, porozumět prognóze nemoci, limitům domácí hospicové péče a souhlasit se spoluprací týmu domácího hospice. Nezbytné je, aby alespoň jedna osoba mohla převzít odpovědnost za nepřetržitou péči o nemocného.

\section{Výzkumná část a její cíle}

Výzkum probíhal $\mathrm{v}$ organizaci, která poskytuje zdravotní a sociální služby dle platné legislativy (tj. dle zákona č. 372/2011 Sb., o zdravotních službách, a zákona č. 108/2006 Sb., o sociálních službách). Konkrétně se jedná o pobytové a terénní služby, centrum denních služeb a sociální poradenství. Hovoříme o organizaci, jejímž hlavním cílem je poskytování péče nevyléčitelně nemocným a umírajícím pacientům. Tato služba zahrnuje i péči o blízké, pečující a rodinné př́islušníky nemocných. Organizace byla založena zástupci tří církví a vychází z humanistických, křestanských základů západní civilizace. Představuje také smysl „agapé = bezpodmínečné lásky“ Otce, Syna a Ducha svatého vycházejícího z Bible. Hlavní provoz organizace - li̊žkového hospice byl zahájen v roce 2008. Jejím hlavním cílem je poskytování hospicové, paliativní péče, tzn. zajištování a zdokonalování komplexní hospicové péče, která nebude limitována místem bydliště ani sociálním statusem nemocného. Ǩídí se standardy paliativní péče, které vydala Česká společnost paliativní medicíny. Cílem hospicové péče je zmírnit bolest, minimalizovat příznaky nevyléčitelného onemocnění, zachovat důstojnost pacienta, zajímat se o duševní stav nemocného a podpořit v péči a doprovázení jeho rodinné př́islušníky či blízké.

Obecným cílem projektu realizovaným $v$ rámci této organizace bylo zjistit možnosti optimalizace postupu multidisciplinárního týmu domácího hospice při př́imu pacienta do domácí hospicové péče za využití australských standardů pro práci s rodinou. Tento proces se skládal ze tří na sebe navazujících částí: (1) analýza a zmapování procesu př́ijmu pacienta do domácí hospicové péče, (2) participativní implementace australských standardů pro př́ijem pacienta, (3) reflexe získané zkušenosti.

\section{Průběh realizace projektu, otázky k metodologii}

Výzkumu se účastnilo 10 členů multiprofesního týmu domácí hospicové péče ( $2 \times$ lékař, $3 \times$ sociální pracovník, $1 \times$ vrchní sestra, $4 \times$ zdravotní sestra). Ostatní profese týmu většinou vstupují do péče až po přijetí pacienta, proto mezi účastníky výzkumu zařazeni nebyli.

Po celou dobu výzkumu byl kladen velký důraz na eticky zodpovědný př́istup $\mathrm{k}$ respondentům; 
protože se jednalo o téměř ojedinělý projekt $\mathrm{v}$ poměrně malém, ale velmi specifickém týmu, museli jsme zajistit, aby byla ochráněna jejich identita i jejich soukromí. Za hlavní metodu sběru dat byl zvolen polostrukturovaný rozhovor individuální, pro závěrečnou fázi zhodnocení implementace pak rozhovor skupinový.

Výzkum byl rozdělen do pěti základních etap a ty následně do dílčích kroků.

Tabulka 1: Realizace participativní organizační změny

\begin{tabular}{|l|l|}
\hline \multicolumn{2}{|l|}{ Představení plánu výzkumu členům multidisciplinárního týmu } \\
\hline 1A & seznámení s australskými standardy \\
\hline 1B & časová náročnost výzkumu \\
\hline 1C & zodpovězení otázek výzkumníkem \\
\hline 1D & nastavení pravidel - etika výzkumu, spolupráce atd. \\
\hline Analýza procesu př́imu pacienta do domácí hospicové péče \\
\hline 2A & individuální polostrukturované rozhovory \\
\hline 2B & zmapování prostředí \\
\hline 2C & identifikace potřeb týmu \\
\hline 2D & př́prava půdy k implementaci \\
\hline Diskuse k nastavení implementace \\
\hline 3A & výběr konkrétních standardů k implementaci \\
\hline 3B & nastavení pravidel a podmínek implementace \\
\hline Implementace \\
\hline 4A & průběh implementace - diskuse na společných schůzkách \\
\hline 4B & závěry k jednotlivým standardům \\
\hline Skupinový rozhovor \\
\hline 5A & závěry skupinového rozhovoru \\
\hline 5B & reflexe a doporučení výzkumníka \\
\hline
\end{tabular}

Zdroj: vlastní zpracování

V první etapě práce (fáze $1 \mathrm{~A}-1 \mathrm{D}$ ) výzkumnice představila plán celého výzkumu na pravidelné poradě týmu domácího hospice. Předala členům týmu překlad jednotlivých australských standardů k nastudování a posouzení jejich př́ípadné vhodnosti pro použití v jejich organizaci. Členové týmu byli seznámeni s časovou zátěží, jakou bude spolupráce na výzkumu pro jednotlivce zhruba představovat, přičemž byly při společné diskusi zodpovězeny související dotazy.

$\mathrm{V}$ druhé etapě proběhly individuální polostrukturované rozhovory se zaměřením na průběh prvního kontaktu s pacientem a jeho rodinou. Během prvních rozhovorů si výzkumnice uvědomila, že bude potřeba otázky upravit $s$ ohledem na předpoklad existence jednotlivých subkultur v týmu. První, velmi koherentní skupinu hovořící „stejným jazykem“ tvořily zdravotní sestry. Druhou skupinu tvořili lékaři a psychologové a třetí, nejvíce heterogenní skupinu tvořili pracovníci sociálního oddělení, půjčovny pomůcek a terénní pracovníci. Cílem této etapy bylo zmapování a analýza současného procesu př́ijmu pacienta do domácího hospice, identifikace potřeb 
týmu a př́íprava půdy pro implementaci vybraných australských standardů.

Ve třetí etapě proběhla diskuse na pravidelné poradě týmu, kde bylo konsenzuálně určeno, které konkrétní standardy budou použity k testování a kdo z členů týmu bude ochoten se implementace zúčastnit.

Ve čtvrté etapě výzkumu proběhla tříměsíční implementace zvolených standardů. Současně probíhaly diskuse týmu na pravidelných schůzkách, kde byla probírána pozitiva a negativa nově nabytých zkušeností.

V etapě páté byl po ukončení implementace uspořádán skupinový rozhovor členů týmu, kteří se jí účastnili.

\section{Etapa č. 2 (2A-2D): Analýza příijmu pacienta do domácí hospicové péče}

V období června a července 2017 proběhly individuální rozhovory s deseti členy multidisciplinárního týmu. Cílem této (výzkumné) etapy bylo zjistit, jaké jsou jednotlivé možnosti prvního kontaktu pacienta (žadatele o domácí hospicovou péči) s týmem domácí hospicové péče, a analyzovat, jakým způsobem kontakt probíhá.

\section{Osobní postup respondenta při prijímání pacienta do domácí hospicové péče}

Z rozhovorů vyplynulo, jaký je obvyklý individuální postup respondenta při přijímání pacienta do domácí hospicové péče. Téměř všichni členové týmu krom jednoho se shodli, že mají svůj vlastní, relativně ustálený systém. Většinou se řídí zkušenostmi z vlastní praxe a poučeni chybami svými i svých kolegů se snaží vybrousit vlastní postup k dokonalosti. Popř́ípadě převzali zavedený postup od svého předchůdce a vyhovuje jim. Mohou také mít postup již natrénovaný tak, aby na nic podstatného nezapomněli. Devět respondentů postupuje dle směrnic organizace pro př́íjem pacienta do domácí hospicové péče, odlišně situaci popisuje pouze jeden respondent: „Úplně ustálený postup nemám, improvizuji dle potřeb týmu a situace v rodiněc (respondent 7).

\section{Vlastní chyby respondentů při př́jmu pacienta do domácí hospicové péče}

Na dotaz týkající se vlastních chyb respondentů, které mohou komplikovat práci ostatním v týmu, uvádějí čtyři respondenti nedokonalé vedení administrativy, konkrétně zapisování dat do elektronického systému: některé chybějící sociální údaje, kontakty na př́ibuzné, není uvedený praktický lékař pacienta atd. Tři z respondentů jsou si vědomi diskuse na téma dokonalejšího vedení dokumentace, snaží se, ale většinou nestíhají: „někdy napišu jen základní údaje a jedu do terénu, pak nestihnu, někdy zapomenu“ (respondent 8). Další tři z respondentů nevědí, ale rádi by na toto téma hovořili v rámci týmu, aby své př́ípadné chyby odstranili. „Nikdo si zatím nějak výrazně nestěžoval, ráda bych o tom diskutovala třeba na supervizi nebo poradě“ (respondent 2). Dva $\mathrm{z}$ respondentů uvedli, že $\mathrm{z}$ důvodu částečného úvazku mívají často prodlevu v činnosti, kterou pro tým vykonávají. Nejsou schopni na tom nic změnit. Nestíhají značný objem práce během své pracovní doby. Dalo by se to ovlivnit pouze na úkor kvality práce, ale ani toto by ve svém důsledku nebylo pro pacienty ani tým domácí hospicové péče žádoucí.

\section{Nevyhovující postupy ostatních členů týmu domácí hospicové péče}

Část rozhovoru se zaměřovala na to, jaké postupy při přijímání pacienta do domácí hospicové 
péče ze strany jejich kolegy jim nevyhovují a proč. Šest z respondentů uvedlo potřebu rychlejší a operativnější spolupráce týmu. Často je trápí zdlouhavý přijímací proces a tím vzniklá časová prodleva pro pacienta. „Pomalá součinnost týmu a nízká flexibilita $z$ důvodu částečných pracovních úvazkü (respondent 2). Čtyři respondenti uvedli jako nevyhovující postup unáhlenost způsobenou snahou pomoci co nejrychleji. Nepodaří-li se při první návštěvě v rodině správně odhadnout situaci, zda vůbec péči o pacienta zvládnou, dochází následně ke stresujícím situacím jak pro pacienta a jeho rodinu, tak pro tým domácí hospicové péče. Následky takového př́imu se řeší obtížně a operativně - většinou překladem pacienta do lůžkového hospice.

\section{Návrhy změn pro snadnější prìímací proces pacienta do domácí hospicové péče}

$\mathrm{Na}$ závěr rozhovorů byli respondenti tázáni, co by jim osobně pomohlo při procesu přijímání pacienta do domácí hospicové péče. Reakce respondentů se nesly především ve smyslu požadavku na zavedení řádu, metodiky, standardů, IT systému, čímž by byl jednoznačně stanoven optimální průběh procesu př́jmu. „Asi nějaké standardy, na co se přesně ptát při prvním kontaktu, a také průběžně mluvit s týmem o chybách a hledat lepši řešeni" (respondent 3). „Nějaký IT systém sdílený všemi, kam informace zapišu a všichni to hned uvidi" (podobně odpověděli respondenti 2, 4, 6 a 7). $V$ rozhovorech zaznělo množství nápadů a přání, $z$ nichž se některé opakovaly. $Z$ toho lze usuzovat, že by bylo vhodné uvažovat o zavedení některých změn plynoucích z potřeb respondentů. Zazněly rovněž návrhy ve smyslu zavedení platného režimu, který by podporoval rychlejší operativní spolupráci týmu mezi jednotlivými profesemi - provoz, který by byl zajištěn dostatečnými úvazky personálu tak, aby bylo možné bez prodlev reagovat na požadavky multidisciplinárního týmu lékař - sestra - sociální pracovník - psycholog. Čtyři z respondentů uvedli, že by jim pomohla jistota operativní konzultace $s$ lékařem. Právě $v$ tomto má tým domácí hospicové péče rezervy, a to především z personálních důvodů vlivem nedostatku lékařủ. Každý člen týmu má nějaký systém, jak postupovat při př́ijmu klienta do domácí hospicové péče. Tyto systémy jsou však individuální, často dokonce situační, nejsou v podstatě vedeny žádnou metodikou. Ze situačně vyvstalé vzájemné interakce těchto individuálních systémů mohou vyplývat určité problémy, které pak komplikují práci jiným členům týmu. Právě tento moment - na kterém se shodli členové zkoumaného týmu - by mohla implementace australských standardů pro př́ijem pacienta potenciálně zlepšit.

\section{Proč právě australské standardy?}

Otázkou zůstává, proč byly zvoleny právě „australské standardy pro práci s rodinou pacienta“. Této volbě předcházelo studium dostupné odborné literatury a konzultace s odborníky v oboru hospicové a paliativní péče. Základním př́nosem této volby byl fakt, že australské standardy jsou určeny pro všechny paliativní pacienty bez ohledu na původní diagnózu, čímž se liší od většiny ostatních standardů, vydaných např. v Německu, Irsku, Kanadě, USA, které jsou zaměřené primárně na onkologické pacienty. Vzhledem k situaci, kdy „podle statistických kritérií patř́ věková struktura obyvatelstva ČR k evropskému průměru, postupně se ale bude dostávat mezi země s nejstarším obyvatelstvem ${ }^{\text {“13 }}$, musíme vzít tento výhled rychle stárnoucí populace v úvahu. V praxi to znamená, že již dnes je možné sledovat mírný nárůst žadatelů o domácí hospicovou péči z důvodu geriatrické křehkosti. Doposud sice geriatričtí pacienti, vyžadující specializovanou paliativní

13 Anna ARNOLDOVÁ, Sociální péče, Praha: Grada Publishing, 2015, s. 136. 
péči, početně nepřevažují nad onkologickými pacienty, musíme se však na tento trend připravit, protože péče o tyto nemocné je po všech stránkách odlišná. Přestože smrt po dosažení určitého věku člověka je předpokladatelná a je přirozeným jevem, lidé na ni nejsou nikdy připraveni. Multiprofesní tým domácí hospicové péče čelí zcela odlišným problémům u mladších onkologických pacientů a starších polymorbidních pacientů. U onkologických pacientů většinou mladšího věku pomáhá tým řešit otázky člověka zasaženého nemocí v produktivním věku. Nezřídka po nich zůstávají malé děti, nevyřešené problémy, pacient se často zaobírá otázkou, proč nemoc postihla právě jeho atd. U geriatrických pacientů vy̌ššiho věku je nutno řešit správné nastavení medikace, na kterou nemocní reagují zcela odlišně než pacienti onkologičtí. Vnímáme zde odlišnost v péči o duševní stav seniora a o zajištění kvalitní ošetřovatelské péče. Vidíme také rozdílné požadavky na péči o pozůstalé, zvláště pokud zůstane druhý partner úplně osamělý. Na druhou stranu mívají senioři již většinou finanční a majetkové záležitosti vyřešené a $\mathrm{v}$ této oblasti pomoc nepotřebují. Všechna tato specifika a rozdílnosti péče jsou $\mathrm{v}$ australských standardech dobře ošetřeny. Jedná se o stále živé, průběžně používané metody, operativně se vyvíjející dle momentální potřeby pacientů. Zahrnují demografické a kulturní aspekty všech regionů Austrálie. Standardy vycházejí opakovaně v nových aktualizovaných verzích.

Dalším argumentem pro použití právě australských standardů je skutečnost, že z nich vychází mnoho dalších národních paliativních společností, včetně nadnárodní Evropské asociace pro paliativní péči (EJPC), při tvorbě standardů a norem paliativní péče ve své zemi. Odkazují se na ně i standardy paliativní péče $v$ Kanadě. ${ }^{14}$

\section{Australské standardy pro práci s rodinou}

Clinical Practice Guidelines for the Psychosocial and Bereavement Support of Family Caregivers of Palliative Care Patients (překlad vlastní) ${ }^{15}$ :

1. V momentě, kdy se pacient rozhodne přijmout paliativní péči, musí být informován o tom, že paliativní péče zahrnuje a podporuje i pečující osoby, rodinné př́slušníky. Těmito mohou být osoby, které pacient považuje za nejbližší. Může to být člen rodiny, partner, př́tel, děti. Nemusí být nutně jeho př́ibuzný.

2. Zeptejte se pacienta, koho určí primární pečující osobou. Pokud označí jen jednu, zeptejte se, zda existuje ještě někdo, kdo by mohl být osloven jako další pečující osoba. Diskutujte s pacientem preference-oblíbenost, možných pečujících osob. Ověřte si, zda si je vědom a souhlasí s tím, že pečující osoby budou zajištovat jeho zdravotní a ošetřovatelskou péči. Uvedte do písemného záznamu-dekurzu jméno hlavní pečující osoby.

3. Seznamte pečující osobu s tím, že byla pacientem vybrána a určena pro tuto roli. Vysvětlete roli, zodpovědnost a typické funkce pečující osoby a ujistěte se, že s tím souhlasí. Pokud je pečující osoba ochotná toto príimout, uvedte její souhlas písemně do dokumentace. Proberte veškeré nejasnosti, které by mohly nastat, včetně konfliktů v rámci rodiny.

4. Proberte $s$ pacientem a pečující osobou detailní plán péče zahrnující veškeré důsledky související se zákonnou odpovědností pečujícího.

5. Vnímejte pečující osoby jako důležitý zdroj informací o pacientovi. Získávejte průběžně

14 () CHPCA, The Canadian Hospice Palliative Care Nursing Standards (on-line), dostupné na: http://www.chpca.net, citováno dne 5. 6. 2017.

15 Peter HUDSON et al., Guidelines for the psychosocial and bereavement support of family caregivers of paliative care patients, Journal of Palliative Medicine 6/2012, s. 696-702.). 
informace od pečujících osob, jejich poznatky, zkušenosti, včetně všech relevantních informací týkajících se pacienta, které by mohly být důležité pro multidisciplinární tým.

6. Vysvětlete pečující osobě, jaké služby a zdroje podpory mohou být poskytnuty týmem domácího hospice. Ujistěte se, že očekávání jsou reálná.

7. Kdykoli je to možné, svolejte schůzku rodiny, nebo skupinu pečujících, včetně pacienta, pokud to lze.

8. Ve spolupráci s pečující osobou provedite identifikaci potřeb pacienta včetně psychických, fyzických, sociálních, duchovních i finančních a praktických záležitostí.

9. Harmonogram péče vytvořte až v momentě, kdy jsou vyjasněny všechny detaily a otázky ohledně poskytovaných služeb domácí hospicové péče s pečující osobou. Teprve potom zahajte péči týmu domácího hospice.

10. Na základě rozhovoru s pečující osobou proved’te analýzu momentálního stavu pacienta, rizika psychické dekompenzace a zajistěte vhodná opatření.

11. Pomáhejte pečující osobě identifikovat signály terminálního stavu - informovat a připravit na to, že smrt přichází. Podrobně informujte pečující osobu o tom, jak postupovat.

12. Zhodnotte míru připravenosti pečujících na smrt pacienta. V momentě úmrtí se ujistěte, že pečující osoba situaci zvládá a zhodnot'te prrípadnou intervenci.

13. Domluvte se s pečující osobou na přesném postupu podpory po úmrtí. Ujasněte si vzájemně, co si v rámci zvyklostí rodiny přejí a co ne. S čím předpokládají, že budou potřebovat pomoc. Dohodněte konkrétní postup př́ípadné intervence týmu.

14. Tým domácího hospice podpoří a zvolí způsob komunikace s pečující osobou a zhodnotí její reakce na úmrtí. V př́padě potřeby zvolí způsob pomoci, s ohledem na stav pečujícího - při krátkodobém, či prodlouženém truchlení. Do podpory zahrne všechny služby, které účinně pomohou v této zátěžové situaci (kde co najít, stacionář, kostel, klub, psychoterapie atd.).

15. Tým domácího hospice a všichni jeho členové jsou o úmrtí pacienta informováni pečující osobou ihned.

16. V čase po úmrtí pacienta člen týmu domácího hospice nabídne podporu v oblastech praktických i duchovních. Pokud smrt nastala doma, zhodnoṫe potřebu návštěvy.

17. Kontaktuje pečující osobu a členy rodiny za účelem posouzení jejich potřeb, adaptace po úmrtí a v době truchlení 3-6 týdnů po úmrtí a upravte plán péče o truchlící dle aktuální potřeby.

18. Vytvořte předběžný plán podpory o truchlící založený na potřebách pečujících osob. Zajistěte předpokládanou identifikaci rizikových faktorů - lidí, podmínek, fyzických, psychických a okolností smrti.

19. Zhodnotte stav a situaci pečující osoby a dalších členů rodiny 6 měsíců po úmrtí pacienta.

20. Po úmrtí pacienta tým domácího hospice ve vhodnou dobu zhodnotí kvalitu dosažené poskytnuté péče. Vyhodnotí, zda tým udělal vše, jak nejlépe bylo možné. Z případných chyb učiní závěry.

\section{Fáze č. 3: výběr standardi̊ pro implementaci $(3 \mathrm{~A}, 3 \mathrm{~B})$}

Součástí vedených rozhovorů byly čtyři otázky týkající se australských standardů pro práci s rodinou. Byl zjištován postoj jednotlivých členů týmu domácí hospicové péče k možnosti využití australských standardů v jejich vlastní organizaci. Postoje byly převážně pozitivní. Čtyři respondenti vnímali možnost vyzkoušení standardů jako potenciální přínos a inspiraci. Tři respondenti 
očekávali, že jim př́padná implementace nových standardů přinese poučení a jasnější pravidla přijímacího procesu. Jeden $\mathrm{z}$ respondentů to vnímal jako možnost $\mathrm{k}$ vyzkoušení inspirujících pravidel, která sám při své práci v týmu postrádá. Uvedl, že sice v podobném duchu tým pracuje, ale nemá taková pravidla oficiálně stanovena, což by, při rozrůstajícím se týmu, uvítal. Zejména nově příchozí kolegové tápou a učí se od ostatních - od každého něco, co komu vyhovuje nejlépe. Jeden $\mathrm{z}$ respondentů uvedl, že každý bod $\mathrm{z}$ australských standardů je možné využít $\mathrm{v}$ ČR, není $\mathrm{v}$ nich nic, čím by byli v týmu omezováni. Další z respondentů se domníval, že „použití australských standardi̊ v našem týmu bude inspirujicí a přinese systematičnost práce" (respondent 10). Cílem individuálních rozhovorů bylo mj. zjistit, v jakém rozpoložení se tým domácí hospicové péče v dané chvíli nachází, zda je současný způsob přijímání pacientů zcela funkční, nebo je zde vůle $\mathrm{k}$ přemýšlení o změnách. Také bylo potřeba vyhodnotit postoj respondentů k australským standardům pro práci s rodinou a jejich ochotu osobně vyzkoušet některé ze standardů ve vlastní praxi. Výsledkem analýzy individuálních rozhovorů bylo zjištění, že tým je kompaktní organismus, který operativně spolupracuje, vždy je schopen domluvy. Na prvním místě zájmu týmu je maximální kvalita péče o pacienta po všech stránkách, tak jak vychází z hodnot hospicové a paliativní péče. Členové týmu vnímají prostor ke zlepšení vlastních nastavených procesů $\mathrm{v}$ př́ijmu pacienta do domácí hospicové péče. Respondenti jsou ochotni investovat svůj čas a energii do implementace australských standardů, a to s očekáváním přínosu inspirace pro možné změny současného přijímacího procesu.

Využití australských standardů ve vlastním týmu vnímá pět členů jako možný př́nos pro optimalizaci systému a řádu v procesu přijímání nového pacienta. Doufají, že díky implementaci vytvoří jakousi kostru př́ijmové návštěvy použitelnou pro celý tým. Tři z respondentů vidí konkrétní pozitiva $\mathrm{v}$ zaměření se na systematickou péči o truchlící v rozmezí 6 týdnů až 6 měsíců po úmrtí. Tomu se v současné době, vyjma setkání pozůstalých $2 \times$ ročně, věnují spíše intuitivně. V Austrálii se věnují péči o pozůstalé ve větší míře než u nás, věnují se i diskusi nad reflexí truchlících, učí se $\mathrm{z}$ př́padných pochybení. Na to by tým mohl klást větší důraz. Dva z respondentů vidí možnost v zaměření se na péči o rodinu jako celek. Rádi by se více věnovali péči o truchlící a detailně zmapovali celou situaci v rodině.

Jedna z otázek polostrukturovaného rozhovoru respondenty vyzývala, aby zvolili čtyři z australských standardů, které by si přáli vyzkoušet v reálné tř́měsíční implementaci - nejlépe takové, které postrádají $\mathrm{v}$ dosavadním systému postupů práce, tedy ty, které by byly z jejich pohledu nejužitečnější a nejúčelnější.

$\mathrm{V}$ tabulce 3 je uveden přehled dvaceti standardů dle toho, jak je respondenti volili k možné implementaci. V prvním řádku nalezneme pořadová čísla všech dvaceti australských standardů uvedených výše ve formě českého překladu. Ve druhém řádku je zaznamenáno, kolik respondentů konkrétní standard vybralo $\mathrm{k}$ implementaci. $Z$ tabulky vyplývá, že nejčetněji, a to $4 \times$, respondenti volili standardy č. 2, 9, 18 a 20.

\section{Tabulka 2: Četnost standardů volených $k$ implementaci}

\begin{tabular}{|l|l|l|l|l|l|l|l|l|l|l|l|l|l|l|l|}
\hline \multicolumn{2}{|l|}{ Četnost volených standardi̊: } \\
\hline Standard číslo & 20 & 18 & 2 & 9 & 19 & 14 & 4 & 5 & 13 & 3 & 6 & 10 & 16 & 1 & 7 \\
\hline Četnost & 4 & 4 & 4 & 4 & 3 & 3 & 3 & 3 & 2 & 2 & 2 & 2 & 2 & 1 & 1 \\
\hline
\end{tabular}

Zdroj: vlastní výzkum 
S tímto závěrem analýzy byli seznámeni členové týmu na následující pravidelné společné schůzce domácí hospicové péče. Tato analýza tvořila jeden $\mathrm{z}$ hlavních ukazatelů pro další proces implementace. Byla opěrným bodem pro konsenzus celého týmu při výběru konkrétních australských standardů pro tříměsíční implementaci. Členové týmu si znovu zopakovali, o které standardy se jedná, probrali jejich detailní zaměření, vzájemně konzultovali a prezentovali své názory, a nakonec se ujistili, že právě tyto standardy tým použije ve svém reálném provozu. Zkušební období bylo stanoveno od 1. 9. do 30.11.2017. Aktivně se implementace účastnilo devět $z$ deseti původních respondentů. Jeden respondent odmítl spolupráci $\mathrm{z}$ vážných časových důvodů.

\section{Fáze č. 4 a 5 (4A - 5B): Implementační proces a jeho reflexe}

Čtvrtá etapa výzkumu, tj. etapa samotné implementace, probíhala v období od záŕí do listopadu 2017. Během prvního měsíce implementace bylo realizováno 12 př́imů, během druhého měsíce 5 a během třetího 4 př́imy pacientů do domácího hospice. Celkem 21 pacientů bylo přijato do domácí hospicové péče s použitím prvků výše vybraných australských standardů pro práci $s$ rodinou. $V$ celém období implementace se členové týmu během pravidelných porad věnovali vzniklým nejasnostem, nejistotám, obavám, postřehům a pozitivním zkušenostem. V průběhu celého implementačního období tak spolu členové týmu průběžně komunikovali a reflektovali probíhající proces.

Jedna schůzka týmu pak byla určena pro celkové zhodnocení dosavadní zkušenosti s implementací standardů pro př́ijem pacienta mj. formou skupinového rozhovoru. Ve stanoveném termínu se sešlo 8 z 9 účastníků implementace. V̌̌ichni zúčastnění se aktivně zapojovali, spolupracovali a realisticky navrhovali či argumentovali, jakými zkušenostmi během proběhlých třech měsíců prošli. V období implementace, která trvala 91 dní, bylo přijato 21 pacientů do domácí hospicové péče. Při těchto př́ijmech byly standardy prakticky vyzkoušeny.

Členové týmu ocenili způsob implementace, zejména podrobné vysvětlení důvodů a způsob jejího provedení a také dostatek času na vstřebání informací o australských standardech. Většině účastníků se se standardy pracovalo dobře a vnímali je pozitivně.

K otázce použitelnosti standardu 2 se čtyři respondenti vyjádřili pozitivně, dva pozitivně s výhradami a dva negativně. Tým jako celek by ale uvítal zavést tento standard ve své organizaci - členové týmu se totiž shodli na tom, že jim usnadňuje práci v rámci týmu, zejména $\mathrm{v}$ oblasti předávání informací o klientovi / rodině klienta. Negativní reakce k tomuto standardu zahrnovaly obavy týkající se zvýšené administrativy a větší časové náročnosti.

K druhému implementovanému standardu 9 se šest účastníků vyjádřilo jednoznačně pozitivně, $\mathrm{s}$ tím, že všichni považovali za nutnost takový standard $\mathrm{v}$ organizaci zavést. Jeden $\mathrm{z}$ respondentů považuje zavedení podobného standardu za zbytečnost.

Třetí standard 18 vyvolal živou diskusi, jejímž závěrem bylo sedm pozitivních postojů pro zavedení a jeden negativní, který argumentoval takto: „A zase ty rizikové faktory, mám už toho dost. Nejsem jasnovidec. Opravdu předpokládat zodpovědně neprèedpokládatelné je jako řešit neřešitelné. Nechávám to na vývoji stavu v rodine“" (respondent 2). Většina však uvažovala v podobném duchu jako respondent 7: „Jedná se o hưre uchopitelný, ale nutný standard. Otázkou je, jak to nejlépe uchopit, tak aby to byl použitelný standard u nás. Zejména nezbytný pro měrení kvality poskytovaných služeb naším týmem. "I tento standard byl tedy vnímán jako př́nosný pro zvyšování kvality poskytovaných služeb.

K poslednímu implementovanému standardu 20 se šest respondentů vyjádřilo pozitivně, tj. pro 
jeho zavedení. Respondent 5 reagoval s výhradami: „Nesdílím vaše nadšení, stále mám problém s terminologií. Co je přesně, vhodná doba'? Jsem pro jasnou specifikaci, a pak bych souhlasil." A respondent 8 zmiňoval obavy: „Jen mám obavy, abychom se v těch všech papirech nakonec neutopili. Jsem pro zavedení stručných, jasných, přehledných, účelných a smysluplných standardü. " $Z$ výpovědí respondentů bylo patrné, že testované standardy v praktické rovině vnímali pozitivně - tj. jako prínosné pro lepší koordinaci práce v týmu a tím i k vyšší kvalitě poskytovaných služeb. Výhrady se týkaly jak terminologických nejasností, tak obav souvisejících s časovou náročností spojenou s implementací vybraných standardů.

Skupinový rozhovor se dále zaměřil na možný zájem ze strany týmu o zavedení změny v oblasti standardů, začlenění některých těchto vyzkoušených standardů do praxe. Na otázku, zda jsou všichni dobře seznámeni s problematikou a záměrem, chápou důvody této prŕípadné změny, respondenti reagovali vesměs souhlasně. Na dotaz, zda je někdo zásadně proti, se nikdo neozval členové týmu vnímali implementaci vybraných standardů pro práci s rodinou jako př́nosnou pro lepší koordinaci práce týmu jako celku.

\section{Doporučení pro praxi, závěry}

Vzhledem k tomu, že se tým domácího hospice aktivně a s opravdovým zájmem zapojil do výzkumu, lze předpokládat, že je zde prostor $\mathrm{k}$ reálné úvaze o zavedení změny. Během výzkumně implementačního procesu se opakovaně ukázalo, že tým je kompaktní živý organismus, který se za každých okolností snaží dělat maximum pro zachování kvalitního fungování. Na základě výsledků $\mathrm{z}$ individuálních rozhovorů i skupinového rozhovoru byla vypracována následující doporučení - ačkoli jsme vycházeli z potřeb konkrétní organizace, domníváme se, že by mohla být inspirací pro další multidisciplinární týmy uvažující o organizační změně za účelem zefektivnění týmové práce a zlepšení kvality poskytovaných služeb:

- Pokud se organizace rozhodne pro zavedení změny, je nezbytně nutné celý proces dobře načasovat, připravit a správnými kroky provést tak, aby měl šanci na úspěch. Tým domácího hospice je fungující organismus citlivě reagující na všechny podněty. Vnímáme, že zde není vhodná direktivní změna „shora“, např. formou nekonzultované změny metodiky.

- Během př́pravné fáze změnového procesu doporučujeme zjistit stav připravenosti organizace na zavedení změny. Např́klad $\mathrm{s}$ využitím některých $\mathrm{z}$ nástrojů „k analýze situace a identifikaci faktorů, které proces změn podporují (tzv. akcelerátory) a které ji blokují (tzv. retardéry) analýzu silového pole. Akcelerátory a retardéry mají opačnou orientaci, ale různou intenzitu. Po posouzení jejich významnosti je možno se rozhodnout pro změnu, nebo setrvání v současném stavu"16.

- Při sestavování plánu postupu zavádění změny doporučujeme držet se osvědčených modelů. Např́ílad by bylo možné použít metodu „Osm kroků úspěšné transformace organizace “17. První krok této metody, konkrétně představení myšlenky zavedení změny, jsme již v rámci výzkumu provedli. Druhým krokem metody je sestavení stabilního týmu z nejvíce motivovaných lidí. Tomuto týmu je potřeba jasně a srozumitelně vysvětlit, co se bude dít a proč. Dủležité je rovněž poskytnout pracovníkům relevantní čas na přijetí této informace a zkontrolovat, $z d a$ toho času bylo skutečně dostatek. Kotter ve své metodě dále

16 Lada FURMANÍKOVÁ, Studijní opora ke kurzu Teorie a praxe ř́zení organizací. Nepublikovaný manuskript, Praha: UK FHS, 2017.

17 John P. KOTTER, Vedení procesu změny, Praha: Management Press, 2000. 
doporučuje zprostředkovávat myšlenku všem pracovníkům, zpracovat detailní postup zavedení změn, zodpovědět všechny vyřčené otázky. Kotterův pátý krok je poté samotná implementace, kdy se doporučuje nastavovat potřebné úpravy dle aktuálních požadavků. Zde tedy doporučujeme upravit standardy do přesných, použitelných, účelných znění pro tým. Šestým krokem metody je stanovení krátkodobých cílů. Tímto způsobem lze poukázat na dílčí úspěchy týmu, motivovat pracovníky k pokračování započatého procesu za maximální podpory, dlouhodobě pracovat na ustálení změny, aby se nevrátil původní stereotypní stav. Sedmým krokem je upevnění dosažené změny, aby se stala automatickou součástí postupu práce týmu.

- Posledním doporučením je zmapování možných rizik, která by mohla komplikovat úspěšné zavedení změny. Jedná se o hledání způsobů, jak rizikům předcházet, př́ípadně hledat možnosti řešení problémů, které by se přece jen vyskytly. Při výzkumu byly detekovány obavy týmu zejména $\mathrm{z}$ nedostatku času, nedostatečného personálního zajištění, stresu z novot a z toho, že pracovníci nebudou vědět, jak změnu správně pojmout.

Zásadní zkušenost, kterou jsme realizací tohoto projektu nabyli, je ta, že jakýkoli proces v organizaci, týmu či společnosti vyžaduje dostatek času k čemukoli, byt̉ jen samotné úvaze o změně. Proces organizační změny týkající se pracovních postupů, kdy se mění zaběhlé, naučené chování, je aktivitou minimálně na několik měsíců, ale spíše na několik let. Sebekriticky se domníváme, že pro zvýšení pravděpodobnosti úspěchu by bývalo bylo vhodné více zapojit členy týmu domácí hospicové péče do samotného procesu př́pravy výzkumu.

Domníváme se, na základě kolektivní reflexe na závěr implementačního procesu, že začlenění vybraných standardů nastartovalo u členů multidisciplinárního týmu hlubší přemýšlení o všech možných cestách ke zlepšení, zjednodušení, zrychlení a zpřesnění koordinace práce - a tím i ke zvýšení kvality poskytovaných služeb. I v tom lze vnímat námi prezentovaný projekt pozitivně: inicioval kolektivní reflexivní proces, který zaměřil pozornost členů týmu k tak důležitým tématům, jako je efektivita pracovních postupů, kvalita poskytovaných služeb, koordinace práce v multidisciplinárním týmu apod. Účast respondentů na výzkumu podnítila jejich aktivitu $\mathrm{v}$ diskusi s ostatními členy týmu, kteř́ se implementace př́mo neúčastnili, ale jen pozorovali výsledný efekt. Nejvýrazněji je ovlivnila vlastní zkušenost s touto zážitkovou metodou. Tým ocenil zejména časový prostor na jednotlivé kroky nutný ke vstřebání nových informací a pochopení, proč $\mathrm{k}$ tomu dochází. Celý proces vzbudil $\mathrm{v}$ týmu pocit, že změnu sám nutně potřebuje, což je podstatný moment pro šanci na úspěch jakéhokoli změnového procesu v organizaci. Za jeden $\mathrm{z}$ nejdůležitějších efektů popisovaného implementačního procesu považujeme to, že členové týmu sdíleným reflexivním procesem došli ke společnému uznání potřebnosti změn v týmu: že jsou pro něj výhodné, př́nosné a že vedou k ušetření času mj. odstraněním dublování úkonů apod.

V otázce použitelnosti australských standardů i pro jiné týmy domácích hospiců můžeme odpovědět kladně. Zejména $z$ důvodu podobnosti postupů a systému práce, který se musí držet platné legislativy a podmínek pro provozování těchto specifických služeb, můžeme nabídnout výsledky výzkumu jako inspiraci jiným týmům napříč republikou.

Práci v domácím hospici lze vnímat jako „smrt přede mnou, smrt za mnou“. Jen stěží bychom nalezli údernější heslo charakterizující tuto profesi. Z pohledu zdravotní sestry s šestiletou praxí hospicové péče vnímá spoluautorka článku tuto službu jako smysluplnou a velmi žádanou. Podpora lidskosti a důstojnosti i v závěrečné fázi života je jedinou zárukou, jak si zachovat maximální 
kvalitu života co nejdéle. Přestože hospicová a paliativní péče u nás nemá nijak dlouhou historii, je jisté, že její význam poroste, česká populace stárne...

\section{Kontakt}

\section{Mgr. Naděžda Adámková}

Univerzita Karlova

Fakulta humanitních studií

Katedra řízení a supervize v sociálních a zdravotnických organisacích

Pátkova 2137/5, 18200 Praha 8 - Libeň

nadezda.adamkova@cestadomu.cz

\section{PhDr. Michal Růžička, Ph.D.}

Univerzita Karlova

Fakulta humanitních studií

Katedra řízení a supervize v sociálních a zdravotnických

organisacích

Pátkova 2137/5, 18200 Praha 8 - Libeň

ruzicka.michal01@gmail.com 